\title{
How Many Children Would You Like to Have? Exploring Romanian Fertility Decline
}

\author{
Iulian Stănescu \\ Research Institute for Quality of Life, Romanian Academy \\ stanescu.iccv@gmail.com
}

\section{Doi:10.5901/mjss.2015.v6n2s5p179}

\begin{abstract}
Since the early 1990s, Romania has experienced population decline. Moreover, the pace of this decline is similar with other Central and Eastern European countries, former members of the Soviet bloc or the former Yugoslavia, and sharper than in Western Europe. Besides migration, of more concern over the long term is the drop in the birth rate. According to data from two nation-wide surveys from late autumn 2014, a plurality of adult Romanians (44\%) has fewer children that they would like to have. A similar share of the population (42\%) has as many children as they would like to have, while a small minority (14\%) has more children than they would like to have. Furthermore, in the less than 36 years of age category, a majority of $63 \%$ declared that they have fewer children that they would like to. This paper explores the issue of low births at individual level to see if there is a relationship between several variables (age, gender, urban/rural residence, ethnic group, subjective well-being, education, marital status, use of Internet) and whether and individual has fewer, as many or more children than he or she would like to. The analysis was performed on a consolidated dataset of 2,131 adults, obtained by merging the datasets of two nationwide surveys, which used the same questions and the same sampling techniques.
\end{abstract}

Keywords: Romania, population decline, births, fertility, children.

\section{Introduction}

For a generation, Europe has experienced demographic decline. The phenomenon raises major economic, social and political issues for the future. While in Western Europe immigration damped the effect of low fertility, most of the countries in Central and Eastern Europe saw their population fall due to a combination of higher mortality, low fertility and emigration.

This paper looks into the fertility decline experienced by Romania in the past quarter century. Following a brief overview of the main theories and explanations for demographic decline, we analyze macro level data covering fertility and population indicators trends in Europe for the past 50 years. In the second stage, we use individual level, nationwide, representative sample data to compare the desired and actual number of children for adult Romanians. Furthermore, we explore the relationship between several variables (age, gender, urban/rural residence, ethnic group, subjective wellbeing, education, marital status, use of Internet) and whether and individual has fewer, as many or more children than he or she would like to.

\section{Method}

The methodology relies on secondary analysis. At macro level, we use population data regarding fertility rates and other population indicators for European countries covering the interval 1960-2012. At individual level, we use sample data from a consolidated dataset of 2,131 adults, obtained by merging the datasets of two nationwide surveys, representative for the adult population of Romania. The data was collected during October 3-8, 2014 (sample size 1,212) and October 21-24, 2014 (sample size 919) by the CCSCC polling company for the Liberal Institute "Brătianu", using the same questions and sample techniques. The surveys were based on a probabilistic tri-stadial stratified sample using the computer assisted telephone survey technique. Phone numbers included both mobile and fixed telephony. The margin of error for the consolidated dataset is $+/-2.12$ at the 95 per cent level of confidence and $+/-2.77$ at the 99 per cent level of confidence. All the variables included in the individual-level analysis are categorical (marital status, age category, level of education, Internet usage, subjective wellbeing, gender). The choice of statistical tests derives from the available variables and their type. The available variables cover social-demographical and economic variables, but do not include cultural or ideational variables. Another missing variable is ethnicity. Although it is present in the dataset, a common issue in Romanian surveys is the under-representation of the Roma/Gipsy population. The reason is that some Roma/Gipsy 
respondents self-report themselves as Romanians. As a result, the Roma/Gipsy group covers 0.8 per cent of the sample, compared to 3. 3 per cent $(620,000)$ at the 2012 census and an estimate of 1.5 million by the Research Institute for Quality of Life in 2002 (Zamfir \& Preda, 2002, 13). No variable in the dataset covers religious affiliation or behaviour. This situation prevents the use of factor analysis or loglinear analysis, which would result in an incomplete model. We therefore opted for the use of the chi-square test for each of the abovementioned variables and a categorical variable regarding the desired versus actual number of children.

\section{Theories and Explanations for Demographic Decline}

In the second quarter of the $20^{\text {th }}$ century, demographers noticed a change in the pattern of population growth across nations and continents. Warren Thompson (1929) introduced a classification of countries in three major types by rate of population growth, according to different combinations of birth and death rates. The first group of countries included the most developed countries of that era, Western Europe and the United States. These countries experienced a rapid decrease in population growth due to low mortality and low fertility. Moreover, the pace of the decline in fertility was so fast that it allowed for a potential population decline in the future. In the second group of countries, both death rates and birth rates were in decline, but mortality was much lower and had fallen much earlier that fertility. Although declining, birth rates were, in relative terms, still high and allowed for a rapid population growth, with rates far higher than compared with the first group. Thompson estimated that declining birth rates would eventually move these countries, mostly from Eastern and Sothern Europe, into the first group. Finally, the great majority $(70-75 \%)$ of the word's population at that time, living in less developed countries and the colonies, featured high fertility and high mortality.

Close to the end of the Second World War, Notenstein (1944) presented the classic formulation of the demographic transition theory. In its most basic form, it states that all societies experience a transition from a pre-modern pattern of high mortality and high fertility to a post-modern one with low mortality and low fertility. At the core of this transition are socio-economic factors, especially modernity's twin processes of industrialisation and urbanisation that led to changes in the way of life, values and norms. According to Notenstein (1953, 13-31), "The new ideal of the small family arose typically in the urban industrial society. It is impossible to be precise about the various causal factors, but apparently many were important. (...) As a consequence, the cost of child-rearing grew and the possibilities for economic contributions by children declined. Falling death rates at once increased the size of the family to be supported and lowered the inducements to have many births."

The demographic transition theory has been debated, the main points of critique being its accuracy and the issue of its development as a generalization. Overall, the historical record of the transition's occurrence represents its strong point. On the other hand, the weak spot comes from the less than successful forecasts regarding the threshold and pace of fertility decline (Kirk, 1996, 365). As noted by Coale $(1973,65)$, the problem accurate forecasting arises because there are more conditions involved in triggering the decline of marital fertility, summed up as the following:

(1) Fertility must be within the calculus of conscious choice;

(2) Reduced fertility must be (perceived) as advantageous;

(3) Effective techniques of fertility reduction must be available.

The causes and conditions of demographic transition are highly relevant for understanding the decline in fertility. For the sake of space, this section presents a very brief overview of this issue.

The decline in mortality is part of the demographic transition and always precedes any decline in fertility. While providing an explanation for the decline in fertility has proven to be a difficult endeavour, the reduction of mortality could be more easily tracked to three processes in Western Europe in the $19^{\text {th }}$ and $20^{\text {th }}$ centuries. First, the development of the modern state fostered public order, investment in sanitation (the Sanitary Movement), famine relief, education and medicine. Secondly, a revolution in medicine around the turn from the $19^{\text {th }}$ to the $20^{\text {th }}$ century allowed the development of medicine and treatments that resulted in a sharp decrease in child mortality, later infant morality and longer life expectancy. Third, this was followed in the mid-20 th century by another wave of innovation in medicine with the discovery of antibiotics and the establishment of universal healthcare systems and/or national vaccination programs. The cumulative effect was the all but eradication of infectious diseases, and their replacement as the main source of deaths by chronic diseases (Schofield, et al. , 1991). In itself, mortality decline is seen more as a condition that the main cause of fertility decline. Research on a direct, close relationship failed to deliver conclusive results, and may even be impossible. Psychological effects are cited as possible results. With longer life spans, humans feel more in control of their own destiny and environment. The worldview of industrial and post-industrial individuals is less fatalistic and passive (Kirk, 1996, 368-369).

Economists have weighed in the debate about the factors of fertility decline, with an approach founded in micro- 
economics and the view of individuals as rational actors (Becker, 1981). The main idea is that in the modern world the economics of childbearing make it economically disadvantageous to have children. A more sophisticated framework put forward by economist Richard Easterlin (1975) featured three determinants: 'demand', the desired number of children, 'supply', the cultural elements related to natural fertility, and 'cost', monetary, time and psychological constraints of having children.

John Calwell's (1976) wealth flow theory of fertility decline provides an interesting explanation for the change from a pre-industrial high fertility regime to a post-industrial low fertility one. Developed from anthropological field studies in Africa, the theory asserts that in pre-modern societies, wealth in the family flows from the children or the younger members to the parents or elders. To this effect, children are akin to insurance for old age and a source of free labour for the household. In modern families, the reverse takes place. Parents invest substantially in the education and future of their offspring. In both cases, there is economically rational behaviour.

A stronger emphasis on cultural and ideational causes was put forward by Ron Lestaeghe (1983). Differences in fertility across societies and the pace of fertility decline are linked to the degree of secularism, materialism and individualism. Changes in the ideological sphere bring about different needs, including the consumption of luxury goods, less intense religious believes and practices, and a strong orientation towards self-fulfilment.

The role of the state is another factor. In addition to the support for public order, public sanitation and the provision of health care, abovementioned, the modern welfare state has enforced laws that prevent the use of child labour and exploitation. In addition, a traditional goals of labour policy include increased the female labour market participation and equal pay. Compulsory education and a broader education policy aiming for more years in the education system have increased the cost of having children in the household. Poverty reduction through education also results in decreased fertility (Sen, 2000). Highly relevant is population policy. In the third quarter of the $20^{\text {th }}$ century, some developing countries aimed to reduce population growth through family planning. China is the best known example. Another less known example is Iran, which after a pro population growth policy in the 1980s has successfully changed course and reduced fertility through an extensive family planning policy (Brown, 2008, 136-140).

The diffusion theory offers an explanation for why the change in the reproductive behaviour of individuals in a given society is much faster than changes in the economic sphere. Mass communication makes the spread of ideas and practices incomparably faster than in pre-modern societies, and the same is applies to fertility control and family planning. Diffusion also covers the spread of contraceptive technology. The effect of the pill in fertility decline in the 1960s and 1970s in Western Europe is a prime example (Murphy, 1993). The social nature of individual decisions is stressed by Carlson $(1966,165)$ : "Birth control behaviour is contagious and the fertility behaviour of a population is not the simple aggregate of isolated individual decisions, but the end product of complex social interactions. " Fertility decline is the result of social networking that spreads and legitimizes birth control. The decision is at the same time a group decision and an individual decision (Cleland \& Wilson, 1987). However, the development of a whole theory on the role diffusion is debated. McNichol $(1992,406)$ sees it as "a description in search of theory".

After reviewing the search for causality in the demographic transition, Dudley Kirk $(1996,379-380)$ put forward four conclusions:

1) Mortality decline is a prime factor, which destabilized the old pattern of high mortality and high fertility;

2) All causes are closely linked and part of the wider process of modernization; each cause emphasizes different element of this process;

3) Once started in Western Europe Fertility, transition spread rapidly and independent of the socio-economic level;

4) The causal factors could be groups in economic and social, on one hand, and cultural and ideational, on the other hand; American tend to favour the former, Europeans the latter; socio-economic factors receive perhaps undeserved dominance due to being easier to measure and hence regarded as more 'scientific'.

Oppenheim Mason (1997) identified four errors in the thinking about demographic transition that stand in the way of a better thinking on the issues:

1) The assumption that transitions in all societies have the same cause: in fact, there are different combinations of causes and conditions;

2) Ignoring mortality decline as a precondition for fertility decline;

3) The assumption that the regulation of fertility is different in pre-transitional and post-transitional societies;

4) Focusing on a decadal time scale. 


\section{Population Decline in Europe and Romania}

In this section we will explore the issue of population decline in Romania at macro level, in a regional and European context. For the past 50 years the world fertility rate has experienced a major decline from slightly above 5 to just below 2. 5 (see Figure 1). The most developed areas in the world during this period, North America and Europe, featured the lowest fertility rate. Within Europe, the dynamic, but not the pace, of fertility decline has followed the initial forecast made by Notenstein (1944), with the rest of the continent following the trend set by the more developed states in Western Europe. Indeed, fertility rates in the rest of Europe - the former Soviet Union and the former members of the Soviet bloc were higher than in Western Europe, while mirroring the overall trend of decline. The states of the former Yugoslavia had lower fertility rates than Western Europe up to the early 1970s, but higher afterwards. The gap between Western Europe and the rest of the continent is also observable if we look at the last year with a total fertility rate above the replacement level (see table 1). The maximum gap is of 16 years, between Western Europe (1976) and the former Soviet Union (1992).

This pattern was changed in the 1990s. After the collapse of Communism, first with the disintegration of the Soviet bloc during the revolutionary year of 1989, followed by the dissolution of the Soviet Union in 1991, and the breakup of Yugoslavia in the 1990s, Central and Eastern Europe experienced a population decline, caused by higher mortality (compared to the previous decades), lower fertility, and emigration. Overall, between 1989 and 2012, these 21 states lost 5. 5 percent of their population total. Moreover, two thirds experienced population decline. Out of these, nine states saw their population reduced by 11 percent or more. With a 14 percent decline in total population, Romania ranks $15^{\text {th }}$ out of 21, and second, behind Bulgaria, out of former Soviet bloc members (see table 2). The causes of this sharp decline, highly unusual in times of peace and without the occurrence of a pandemic, has been debated by social scientist. The shock therapy strategy of the transition from a Soviet-style economy to a capitalist one in the early 1990s, which featured mass privatisation, high unemployment, lower living standards, explosion of poverty and increased social and economic inequality, was identified as a crucial determinant in adult mortality dynamics in post-communist countries in a seminal article authored by Stuckler, King and McKee (2009). In the case of Romania, the transition strategy was critically analyzed by Zamfir (2004).

In the $21^{\text {st }}$ century, policy makers in Europe face the problem of population decline and the associated long term effects on the economy and society. Population or family support policy - with the goal to raise fertility rates - is a topic of public and academic debate (Gauthier, 2007; Heran, 2013; Luci-Greulich \& Thevenon, 2013). Recent studies focused on Europe's demographic challenge (Grant, et al. , 2004; Hoorens, et al. , 2011) found that while immigration in the EU would not prevent aging and its consequences, governments could slow down, but not reverse the population decline by policies aimed at raising fertility. However, such policies have limitations: they are not universal, but context-dependent, take time and deliver change slowly, and no single policy could be recommended.

2015 marks a quarter of a century of demographic decline in Romania. 1989 was the last year with population growth, but also the last year with a fertility rate above replacement level. The dynamic of Romania's birth rate features several peculiarities. In the early 1960s, the country experienced a serious reduction of births. In fact, in 1964 the fertility rate dropped below the replacement level. In 1966, the authorities at the time, at the personal initiative of the Communist Party general secretary, took the decision to limit abortion to serious medical situations. As a result, fertility jumped to 3. 6 the following year (see figure 1). Over a 20-year period, this surge of fertility would result in a population increase of almost 40\% (from 16. 6 million in the 1960s to 23. 2 million in 1989), putting a severe strain on the dependency rate, education, healthcare, and social services. However, the population adapted and controlled fertility through different means, in spite of the official government pro-natalist policy (Zamfir, 1999). In spite of the official ban on abortion and the unavailability of the pill, fertility was controlled, gradually returning close to the average of the Soviet bloc. After the 1989 Revolution, the difficult socio-economic context of the transition and the abandonment of the pro-natalist policies of the old regime (abortion was liberalized) led to a severe drop in the number of births, with a fertility rate of around 1. 3-1. 4, well below the replacement level. The main features of fertility in Romania in the subsequent decades since 1990 are: an increase of the age of the mother at the first birth, from the 20-24 category to the 25-29 age group, which also replaced the former as the one with the highest share of births; persistent high prevalence of abortion compared to other European countries, despite a decline from the high water mark of 1990 (close to 1,000,000 registered abortions); pre-modern pattern of extra marital births (young women from deprived areas, with low or no education); a breakdown in occupational status of the mother into two major groups: employed, 48 per cent, and not employed, 44 per cent (Rotariu, 2010; Rotariu \& Voineagu, 2012). In the 2010s, Romanian fertility rates are below, but close to the European average, which is still far below the replacement level (see figure 2). Moreover, it is very similar to other European countries in the same region and/or with a similar level of development. The complexity of Europe's fertility problem is observable in the low 
correlation between GDP/per capita and the fertility rate ( 0.2 for 2012 data, see figure 2). At the present fertility rate, and with no changes due to increased emigration, Romania's population is forecasted to decrease by 1 million inhabitants per decade, reaching 17 million in the 2030s and less than 15 million by 2050 (Gheţău, 2012). In comparison, the population total stood at 23. 2 million in 1989.

\section{Data and Variables}

The available dataset allowed for an analysis of the difference between two continuous variables regarding the desired and the actual number of children. The key question regarding the former was drafted as follows: "how many children would you like to have or would have liked to have?" (The past tense phrasing took into consideration the part of the population no longer able to have children due to biological reasons). The overall result is interesting, considering the low fertility rate in Romania (see table 3). 27. 6 per cent of respondents declared that they have no children, but only 8.7 per cent stated they would not like to have children. While the share of respondents that would like to have a single child is quasi similar, the share of respondents that would like to have three or more children is higher than the share of respondents that declared they have three or more children. In addition, the mean for the former variable is 2.05 , while for the latter is 1. 46.

By using the difference between these two continuous variables we computed another variable that accounts for the difference between the desired and actual number of children. In a further stage, we recoded this variable into another, categorical variable. A frequency analysis of this variable showed that a plurality of adult Romanians in the sample (44 per sent) have fewer children that they would like to have; a similar share (42 per cent) have as many children as they would like to have, while a small minority (14 per cent) have more children than they would like to have. The relationship between this variable and the following socio-demographical variables was analysed using the chi-square test:

- gender

- age category, with four age groups: $18-35,36-49,50-64,65$ and older

- urban/rural residence

- subjective wellbeing, used as alternative for income (estimation of household total income compared to needs), with the following categories: we have everything we need, without great effort; we are able to buy more expansive goods, but with some effort; we have enough for decent living, but we can not afford more expensive goods; we have enough for basic needs, we do not have enough even for basic needs

- education: primary school or no education, general school (lower secondary education), vocational school (upper secondary), high school, post-secondary and non-tertiary school/college, higher education

- martial status: unmarried, married, divorced, separated, widow

- Internet usage: yes or no.

\section{Results}

There was a significant association between whether a person has fewer, more or as many children as he or she would like to have and the following (in descending value of the test statistic): martial status $\left(x^{2}(8)=228.44, p<0.001\right.$ ), age category $\left(X^{2}(6)=150.29, p<0.001\right)$, education $\left(X^{2}(10)=82.75, p<0.001\right)$, Internet usage $\left(x^{2}(2)=51.15, p<0.001\right)$, urban/rural residence $\left(X^{2}(2)=33.40, p<0.001\right)$, and subjective wellbeing $\left(X^{2}(8)=25.68, p<0.001\right)$. There was no significant association with gender (see table 4).

The results for martial status are in line with the martial predominance of Romanian fertility. 73. 9 per cent of unmarried respondents (adjusted standardized 13. 8) have fewer children than they would like to. The other way around, 26. 7 per cent of widows and widowers respondents have more children than they would like to (adjusted standardized 4. 8).

The age category features similarities with martial status. In the 35 years of age and less group, 62.3 per cent have fewer children than they would like to (adjusted standardized 11. 3). At the opposite end, 19. 9 per cent of those aged 65 and older say they have more children than they would like to (adjusted standardized 3. 5).

In terms of education, a majority of respondents with higher education (57. 1 per cent, adjusted standardized 6. 3) declared they have fewer children than they would like to. In comparison, 24. 4 per cent of respondents graduates of general school (adjusted standardized 4. 8) and 21. 4 per cent of respondents in the primary school or with no education category stated they have more children they would like to. 
Almost two thirds (64. 8 per cent, adjusted standardized 5. 5) of Internet users (57. 6 per cent of the sample) have fewer children than they would like to, while 20. 2 per cent of people that do not use the Internet have more children than they would like to.

\section{Discussion}

Since 1990, for over a quarter of a century, Romania has experienced population decline. The trend is similar with other countries from Central and Eastern Europe. In a quarter of a century, Romania lost 14 per cent of its population. The country ranks second to Bulgaria among former Soviet bloc members and $15^{\text {th }}$ out of 21 states that are former members of the Soviet Union, Soviet bloc or Yugoslavia. After shadowing the declining fertility trend of Western Europe, but with higher fertility rates up to the 1990s, Central and Eastern European countries entered a new stage in their demographic transition, with fertility rates below Western Europe. In addition to higher mortality, Central and Eastern European countries, including Romania, face population decline or stagnation due to emigration to Western Europe.

This paper also explored the issue of low births in Romania at individual level by using sample data. The analysis had its limitations in the fact that too few variables were available, especially covering cultural and ideational factors. The main findings point to a potential for increased fertility. In other words, there is a low birth rate in Romania despite Romanians wanting more children. The mean of desired children in the sample is 2.05 , compared to a mean of 1.46 for actual children. A plurality of adult respondents in the sample (44 per cent) has fewer children that they would like to have. A comparable share (42 per cent) has as many children as they would like to have. Finally, a small minority (14 per cent) has more children than they would like to have. Moreover, the majority of those with fewer children than they would like to have are from the aged up to 35 , unmarried, more urbane, with higher subjective wellbeing, Internet using strata. Further research, especially qualitative, should provide a wider understanding of the reasons underpinning these results.

\section{Tables and Figures}

Table 1. Critical years for the total fertility rate in Central and Eastern Europe

\begin{tabular}{lcc}
\hline & last year above replacement level & year with lowest TFR \\
EU-15 & 1976 & 1998 \\
former Yugoslavia & 1984 & 2006 \\
AC 8+1 & 1988 & 2002 \\
Romania & 1989 & 2001 \\
former Soviet Union & 1992 & 2001 \\
\hline
\end{tabular}

Source: The World Bank

Note: AC 8+1 includes 8 former Soviet bloc and former Yugoslavia states that acceded European Union in 2004, plus Bulgaria

Table 2. Population dynamics in European states, former members of the Soviet bloc, Soviet Union or Yugoslavia

\begin{tabular}{ccccc}
\hline Former part of... & Country & $\begin{array}{c}\text { 1989 population } \\
\text { Millions }\end{array}$ & $\begin{array}{c}\text { 2012 population } \\
\text { Millions }\end{array}$ & $\begin{array}{c}\text { Difference } \\
\text { Percentage }\end{array}$ \\
\hline USSR & Azerbaijan & 7.2 & 9.4 & 31.5 \\
YUG & FYR Macedonia & 2.0 & 2.1 & 4.5 \\
YUG & Slovenia & 2.0 & 2.1 & 3.5 \\
Soviet bloc & Slovakia & 5.3 & 5.4 & 2.3 \\
Soviet bloc & Czech Rep. & 10.3 & 10.5 & 1.8 \\
YUG & Montenegro & 0.6 & 0.6 & 1.1 \\
Soviet bloc & Poland & 38.1 & 38.5 & 1.1 \\
USSR & Russia & 148.3 & 143.5 & -3.2 \\
Soviet bloc & Hungary & 10.4 & 9.9 & -4.6 \\
YUG & Serbia & 7.6 & 7.2 & -5.5 \\
USSR & Georgia & 4.8 & 4.5 & -6.7 \\
USSR & Belarus & 10.2 & 9.5 & -7.1 \\
YUG & Croatia & 4.8 & 4.3 & -11.1 \\
& & & & \\
& & -.0 & &
\end{tabular}




\begin{tabular}{ccccc} 
USSR & Ukraine & 51.9 & 45.5 & -12.3 \\
Soviet bloc & Romania & 23.2 & 20.0 & -14.0 \\
YUG & Bosnia-H. & 4.5 & 3.8 & -15.5 \\
USSR & Estonia & 1.6 & 1.3 & -15.6 \\
USSR & Armenia & 3.5 & 3.0 & -16.0 \\
Soviet bloc & Bulgaria & 8.7 & 7.3 & -16.6 \\
USSR & Lithuania & 3.7 & 3.0 & -20.1 \\
USSR & Latvia & 2.7 & 2.0 & -24.4 \\
Total & & 351.3 & 333.2 & -5.2 \\
\hline
\end{tabular}

Source: The World Bank

Table 3. Breakdown of the sample by the respondent's desired and actual number of children

\begin{tabular}{ccc}
\hline Number of children & Desired & Actual \\
\hline 0 & $8.7 \%$ & $27.6 \%$ \\
1 & $24.8 \%$ & $25.4 \%$ \\
2 & $37.2 \%$ & $29.2 \%$ \\
3 & $16.9 \%$ & $12.4 \%$ \\
4 and more & $12.4 \%$ & $5.4 \%$ \\
\hline Mean & 2.05 & 1.46 \\
Median & 2.0 & 1.0 \\
Std. Deviation & 1.26 & 1.28 \\
\hline
\end{tabular}

Source: Survey database

Table 4. Chi-Square tests output

\begin{tabular}{ccccc}
\hline Variable & N of valid cases & df & Pearson Chi-Square & Asymp. Sig. (2-sided) \\
\hline Marital status & 2,063 & 8 & 228.440 & $0.000^{*}$ \\
Age & 2,063 & 6 & 150.286 & $0.000^{*}$ \\
Education & 2,062 & 10 & 82.747 & $0.000^{*}$ \\
Internet usage & 2,049 & 2 & 51.145 & $0.000^{*}$ \\
Urban/rural residence & 2,063 & 2 & 33.396 & $0.000^{*}$ \\
Subjective wellbeing & 2,025 & 8 & 25.682 & $0.001^{*}$ \\
Gender & 2,063 & 2 & 3.981 & 0.137 \\
\hline
\end{tabular}

$$
\text { * } p<0.001
$$

Source: survey database

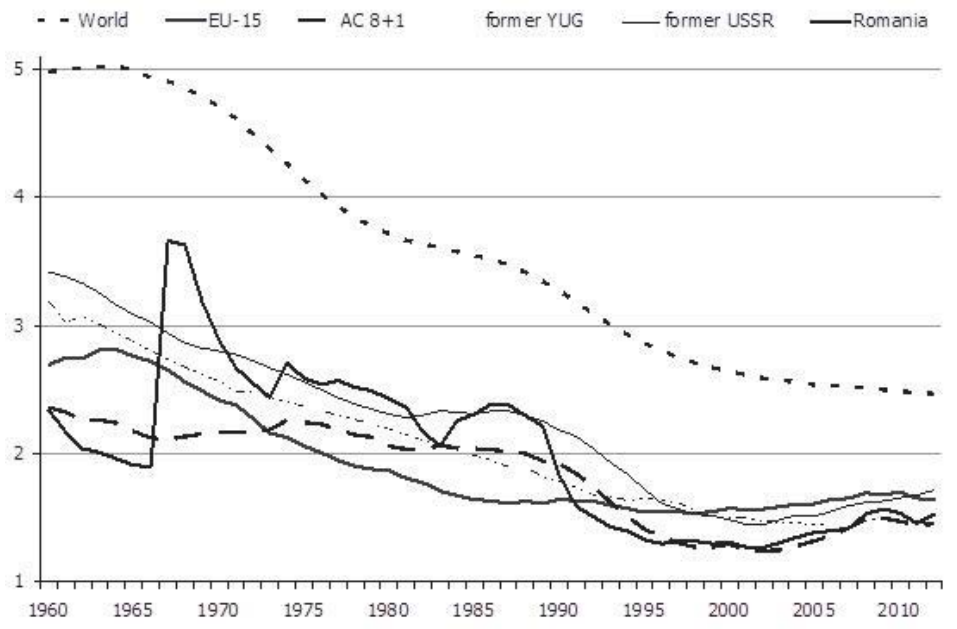

Figure 1. Total Fertility Rate post 1960

Source: The World Bank 


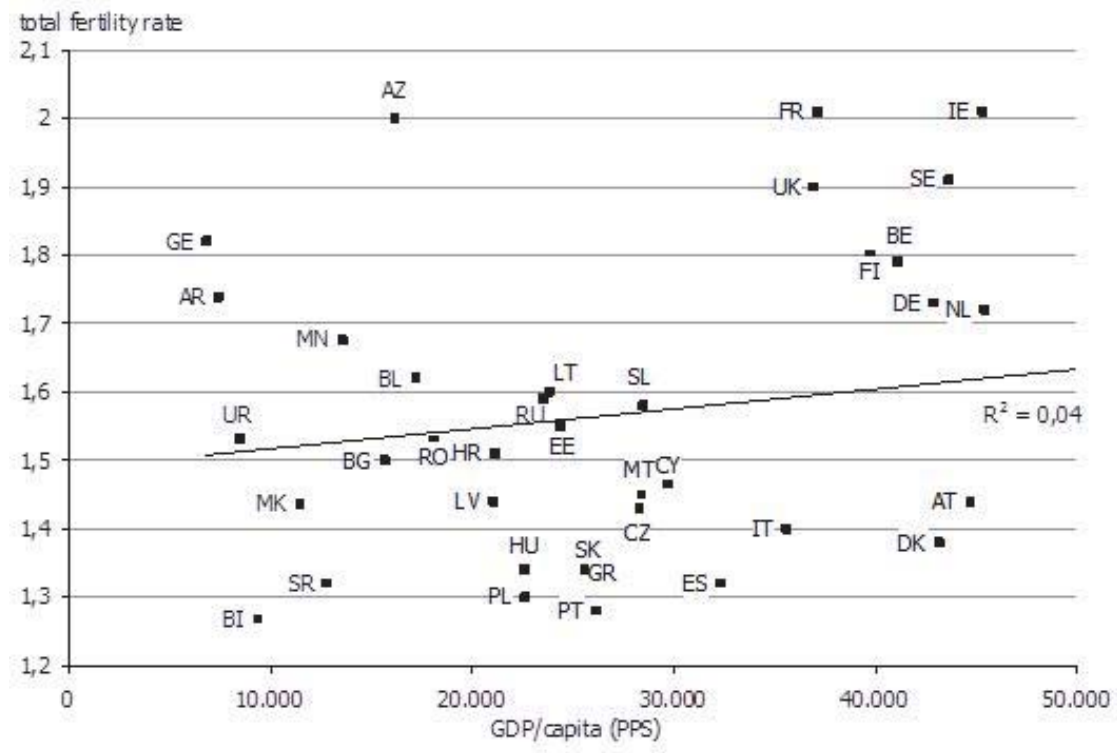

Figure 2. Total Fertility Rate and GDP per capita (PPS) in Europe in 2012

Source: The World Bank

\section{Acknowledgement}

This paper is made and published under the aegis of the Research Institute for Quality of Life, Romanian Academy, as a part of a research programme co-funded by the European Union within the Operational Sectorial Programme for Human Resources Development through the project for Pluri and interdisciplinary in doctoral and post-doctoral programmes. Project Code: POSDRU/159/1. 5/S/141086.

\section{References}

Becker, G. S. (1981). A Treatise on the Family. Cambridge, Mass. : Harvad Unviersity Press.

Brown, L. R. (2008). Plan B 3. 0 Mobilizing to save civilization. New York: WW Norton \& Company.

Caldwell, J. C. (1976). Towards a restatement of demographic theory. Population and Development Review, 2, 321-366.

Carlson, G. (1966). The decline of fertility. Innovation or adjustment process? Population Studies, 20 (2), 147-174.

Cleland, J. , \& Wilson, C. (1987). Demand theories of the fertility transition. An iconoclastic view. Population Studies, 41 (1), 5-30.

Coale, A. J. (1973). The demographic transition reconsidered. In Proceedings of the International Population Conference 1973 Liege, 53-73.

Easterlin, R. (1975). An Economic Framework for Fertility Analysis. Studies in Family Planning, 6, 54-63.

Gauthier, A. H. (2007). The impact of family policies on fertility in industrialized countries: a review of the literature. Population Research and Policy Review, 26 (3), 323-346.

Gheţău, V. (2012). Drama noastră demografică. Populaţia României la recensământul din octombrie 2011. Bucureşti: Compania.

Grant, J. , et al. (2004). Low Fertility and Population Ageing. Causes, Consequences and Policy Options: RAND Corporation.

Heran, F. (2013). Fertility and family-support policies: what can we learn from the European experience? In 27th International Population Conference, Busan, South Korea.

Hoorens, S. , et al. (2011). Low fertility in Europe. Is there still reason to worry? : RAND Europe.

Kirk, D. (1996). Demographic Transition Theory. Population Studies, 50, 361-387.

Lesthaeghe, R. (1983). A century of demographic and cultural change in Western Europe. An exploration of underlying dimensions. Population and Development Review, 9 (3), 411-435.

Luci-Greulich, A. , \& Thevenon, O. (2013). The impact of family policy packages on fertility trends in developed countries. European Journal of Population, 29 (4), 387-416.

McNichol, G. (1992). The agenda of population studies. A commentary and a complain. Population and Development Review, 18 (3), 399-420.

Murphy, M. (1993). The contraceptive pill and female employment as factors in fertility change in Britain 1963-80: a challenge to the conventional view. Population Studies, 47 (2), 221-243.

Notenstein, F. W. (1953). Economic problems of population change. In Proceedings of the Eighth International Conference of 
Agricultural Economists, New York, 13-31.

Notenstein, F. W. , et al. (1944). The future population of Europe and the Soviet Union : population projections 1940-1970. Geneva: League of Nations.

Oppenheim Mason, K. (1997). Explaining fertility transitions. Demography, 34 (4), 443-454.

Rotariu, T. (2010). Studii demografice. Iaşi: Polirom.

Rotariu, T. , \& Voineagu, V. (Eds. ). (2012). Inerţie şi schimbare: dimensiuni sociale ale tranziţiei în România. Iaşi: Polirom.

Schofield, R. , et al. (Eds. ). (1991). The Decline of Mortality in Europe. Oxford: Clarendon Press.

Sen, A. (2000). Development as Freedom. New York: Anchor.

Stuckler, D. , et al. (2009). Mass privatisation and the post-communist mortality crisis: a cross-national analysis. Lancet (373), $399-407$. Thompson, W. S. (1929). Population. American Journal of Sociology, 34 (6), 959-975.

Zamfir, C. (1999). Tranziţia demografică şi problemele sociale asociate. In C. Zamfir (Ed. ), Politici sociale în România: $1990-1998$ (pp. 149-181). Bucureşti: Expert.

Zamfir, C. (2004). O analiză critică a tranziţiei. Ce va fi "după"? laşi: Polirom.

Zamfir, C. , \& Preda, M. (2002). Romii în România. Bucharest: Expert. 